Proceedings of the 10 $10^{\text {th }}$ International Scientific Conference Rural Development 2021

Edited by assoc. prof. dr. Judita Černiauskienè

ISSN $1822-3230$ (Print)

ISSN 2345-0916 (Online)

Article DOI: http://doi.org/10.15544/RD.2021.066

\title{
IMPACT OF NITROGEN TAX ON NITROGEN USE IN LITHUANIA
}

\begin{abstract}
Aušra NAUSÉDIENE், Department of Applied Economics, Finance and Accounting, Faculty of Bioeconomy Development, Vytautas Magnus University, K. Donelaičio g. 58, LT-44248 Kaunas, Lithuania, ausra.nausediene@vdu.lt (corresponding author)

Andreas MEYER-AURICH, Leibniz Institute for Agricultural Engineering and Bioeconomy, Department of Technology Assessment and Substance Cycles, Max-Eyth-Allee 100, 14469 Potsdam, Germany, AMeyer-Aurich@ @atb-potsdam.de

Astrida MICEIKIENĖ, Department of Applied Economics, Finance and Accounting, Faculty of Bioeconomy Development, Vytautas Magnus University, K. Donelaičio g. 58, LT-44248 Kaunas, Lithuania, astrida.miceikiene@vdu.lt

The use of nitrogen fertilizers inevitably causes external negative effects that can be mitigated by various means. This study focusses on tax of mineral nitrogen fertilizer. A study "Farmers' Response to Rise in Mineral Fertilizer Price" investigates the potential response of farmers to a possible tax on mineral nitrogen fertilizer use in Lithuania. Used survey method of data collection, therefore, a questionnaire was conducted to ask farmers, how they would adapt their fertilizer practice to a mineral nitrogen fertilizer tax. Research object: the impact of the nitrogen tax on nitrogen use. Research aim: to identify farmers' response to changed prices for nitrogen fertilizer. Farmer's responds were used to model the reaction of farmers to a tax. The obtained results showed a negative reaction in terms of mineral nitrogen fertilizer use to the rise in mineral fertilizer price. Furthermore, farmers tended to switch to crops with lower nitrogen fertilizer requirements. Price elasticity of demand for mineral fertilizers founded inelastic.
\end{abstract}

Keywords: nitrogen mineral fertilizer, nitrogen tax, farmers' response to the fertilizer price, price elasticity of demand for mineral fertilizers, nitrogen use rates.

\section{INTRODUCTION}

Environmental pollution in agriculture has become one of the most sensitive topics of the last decade. The use of nitrogen fertilizers inevitably causes external negative effects, but is inevitable due to the increasing food demand, limited fertile lands and other factors. The EU has set out to become climate-neutral by 2050, and the European Green Deal strategy defined in the Communication provides for reduction in the fertilizer use by promoting organic farming (Guyomard et al., 2020). The programme of the Lithuanian Government anticipates $30 \%$ reduction in the GHG emissions by 2030 by applying the measures that would help the agriculture become a less GHG-intensive sector. Generally, fertilizer use in Lithuania has to comply with EU (Nitrate Directive) and national regulations and requires fertilization plans on each farm. In practice, Lithuanian farmers are not forced to fully control the amount of mineral nitrogen added to the soil. Recommended nitrogen norms are used according expected yield.

The researchers have noted that excessive use of nitrogen is environmentally damaging and causes pollution issues, as the farmers are using excessive amounts of $\mathrm{N}$ fertilizers to maximize the profit from the sale of products (OECD, 2020; Finger, 2012; Rajsic \& Weersink, 2008; Choi \& Feinerman, 1995; Meyer-Aurich et al., 2010). The higher damage for nature comes from mineral than organic fertilizers use, therefore attention should be focused on that first. It is difficult to control how much organic fertilizer is used on farms. The use of organic fertilizer is mostly originated by the animal husbandry in the farms. By EU regulation this is restricted to the amount of manure containing $170 \mathrm{~kg} \mathrm{~N} / \mathrm{ha}$ (European Commission, 2018). Therefore, it can be expected that farmers rather respond to economic incentives on mineral fertilizer application than on organic fertilizer application. Since farmers as in a business seek generation of profit, existing price structures might create an incentive to use nitrogen at higher than the recommended rates (Meyer-Aurich \& Karatay, 2019). In some situations, plant demand for nitrogen is not balanced by nitrogen rates and is not adjusted to the nitrogen amount already available in soil (Staugaitis et al., 2007).

Nitrogen tax is one of the financial instruments for reducing negative externalities and environmental pollution. Mineral fertilizer use can potentially be controlled by imposing an nitrogen tax (Hellsten et al., 2019). A tax on nitrogen can be regarded as an environmental tax, which are an economic measure performing respective social and environmental functions. The environmental function involves preservation of the environment and reduction of the pollution (Ottaviani \&

Copyright (C) 2021 The Authors. Published by Vytautas Magnus University. This is an open-access article distributed under the terms of the Creative Commons Attribution License (CC BY 4.0), which permits unrestricted use, distribution, and reproduction in any medium, provided the original author and source are credited. 
Scialabba, 2011) rather than collection of additional revenues into the national budget (Verma \& Gayithri, 2018). These taxes are also based on the social function, namely, the polluters' liability and the social damage resulting from the pollution that creates the marginal social cost. Collected incomes from polluters could be allocated to compensate the externalities or distributed back to the agricultural sector. In presence of a tax, it can be expected that farmers reduce their nitrogen fertilizer use, but information about the response of farmers is scant.

The controversial nature of the $\mathrm{N}$ fertilizer tax has been determined by the insights developed by the researchers. The first assumption made is that the price on goods or services may increase due to the tax applied and aimed at internalization of the negative externalities (Štreimikienė \& Ališauskienė-Šeškienė, 2013; Folkens et al., 2020; De Schutter, 2017; Freebairn, 2020), and the new product price that includes the tax is ultimately paid by the buyer rather than the polluter (Keeler et al., 2016; Folkens et al., 2020). Nonetheless, the growing prices on fertilizers lead to reduced purchases (Brunelle et al., 2015) and, consequently, lower GHG emissions as a result of the less intensive use of nitrogen fertilizers. The second insight is reflected by the assumption that the price of the nitrogen fertilizer demand is inelastic to the tax (Finger, 2012; Andersen, 2009; Rougoor et al., 2001; Drake, 1998; Schmidt et al., 2017; Von Blottnitz et al., 2006; Quddus et al., 2008). The economic justification and evidence obtained by empirical studies are insufficient neither for justification, nor for rejection of this position, and the research studies related to nitrogen fertilizer taxation remain relevant as the research area.

This paper presents an empirical approach to estimate price elasticity of demand for mineral fertilizers through farmers' reaction on nitrogen price changes. Research object: the impact of the nitrogen tax on nitrogen use. Research aim: to identify farmers' response on nitrogen use taking in account price changes regarding nitrogen tax. Price elasticity of demand for mineral fertilizers allows to evaluate the nitrogen tax impact on nitrogen use and make recommendations for further evaluations. This elasticity coefficient has been shown to be rather inelastic in many studies, also indicating a huge range of possible elasticities (Hellsten et al., 2019; OECD, 2001; Finger, 2012; Rougoor et al., 2001; Schmidt et al., 2017; Von Blottnitz et al., 2006). Thus, economic incentives might have limited effects on purchase of mineral fertilizers, depending on the elasticity of demand. The impact of nitrogen tax on nitrogen use is analyzed through price elasticity of demand in this study.

\section{MATERIAL AND METHOD}

In order to find out farmers' possible response to changed prices for nitrogen fertilizer a questionnaire was set up. The questionnaire "Farmers' Response to Rise in Mineral Fertilizer Price consisted of 8 questions, which consisted of the following guidelines: type of farm, farm size, type of fertilizer using, use of nitrogen norms on yield, reduced amount of nitrogen in reaction to increased price, comments. Basic demographic background of the farmers was not asked. The survey was conducted from 16 August 2019 to 16 October 2019.

Survey questionnaires were distributed to farmers during a farmers accounting training at the VMU Agriculture Academy in summer 2019. This training under a funded project invited farmers and others related with agriculture activity. Questionnaires were spread for farmers directly by lecturers. In addition, the questionnaire was sent by email to the Lithuanian Farmers Union for further distribution among farmers.

Data were processed in SPSS and Microsoft Excel programs. The price elasticity of demand was calculated for three levels of taxes on fertilizer prices (25, 50 and 100 percent). For tax scenario respondents were asked to what percentage they would reduce the purchase of nitrogen fertilizer. Nitrogen surplus was calculated according to determined nitrogen values. Furthermore, the farmers were given opportunity for comments. The investigation was conducted at indicated stages (Fig. 1).

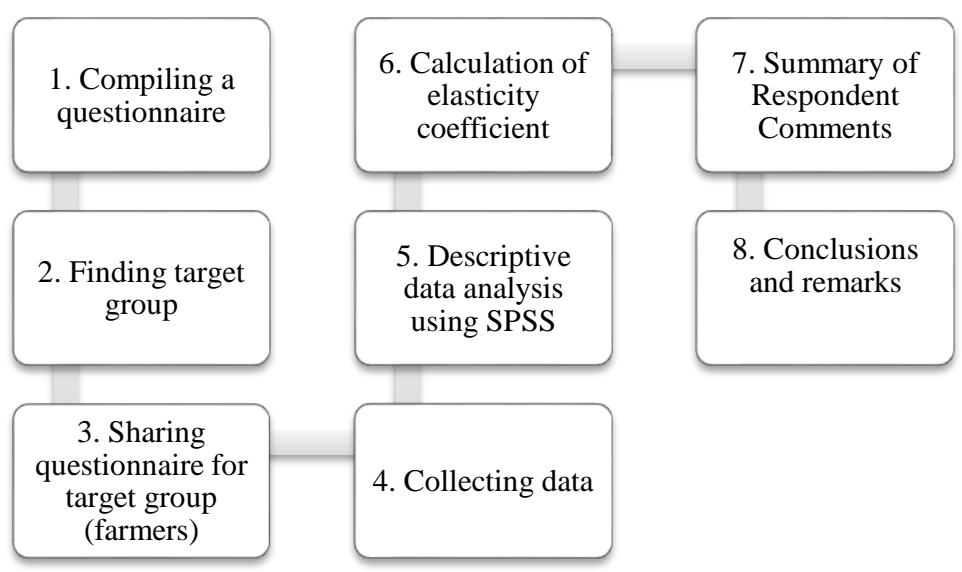

Figure 1. Study flowchart 
A survey method was used to evaluate the response of farmers to changes in the prices of mineral fertilizers, including that they may also be due to the nitrogen fertilizer tax. This type of research is conducted using a survey method, however, there is a lack in this area of studies in order to develop the discussion or compare the results.

\section{RESULTS AND DISCUSSIONS}

Of 25 paper questionnaires distributed, 21 replies were received, of which 17 were fully filled out. The questionnaire, which was sent by e-mail for Lithuanian Farmers Union, received ten online responses. There is no knowledge about how many farmers got that questionnaire by e-mail. The total number of respondents is 35 of which 28 fully filled out questionnaires.

The composition of farms in the survey is distributed as follows: general field cropping, mixed cropping (39.3\%), specialist cereals, oilseeds and protein crops (28.6\%), field crops-grazing livestock, combined (14.3\%), specialist dairying $(7.1 \%)$, horticulture and permanent crops, grazing livestock, specialist granivores $(3,6 \%)$ and no various crops and livestock combined. Most farms agriculture area was up to 292 ha (79.3\%), from 292 to 582 ha (10.3\%), from 582 to 872 ha and from 1162 to 1452 ha $(3.4 \%)$.

The type of fertilizer used was distributed as follows: only mineral (25.9\%), more mineral than organic (44.4\%), only organic $(11.1 \%)$, more organic than mineral (18.5\%). On whether farmers use the recommended rates for $\mathrm{N}$ fertilization answer distributed as follow: yes $(81.4 \%)$, no (14.8\%), other (3.7\%). A link between of type of fertilizer and compliance with recommended $\mathrm{N}$ fertilizer norms can be looked at: $83.3 \%$ of respondents who use more mineral than organic fertilizers follow recommendation for $\mathrm{N}$ fertilization rates. Farmers who use just mineral fertilizers $100 \%$ use recommended rates for $\mathrm{N}$ fertilization, however, who use more organic than mineral does not follow recommended $\mathrm{N}$ rates $(40 \%)$.

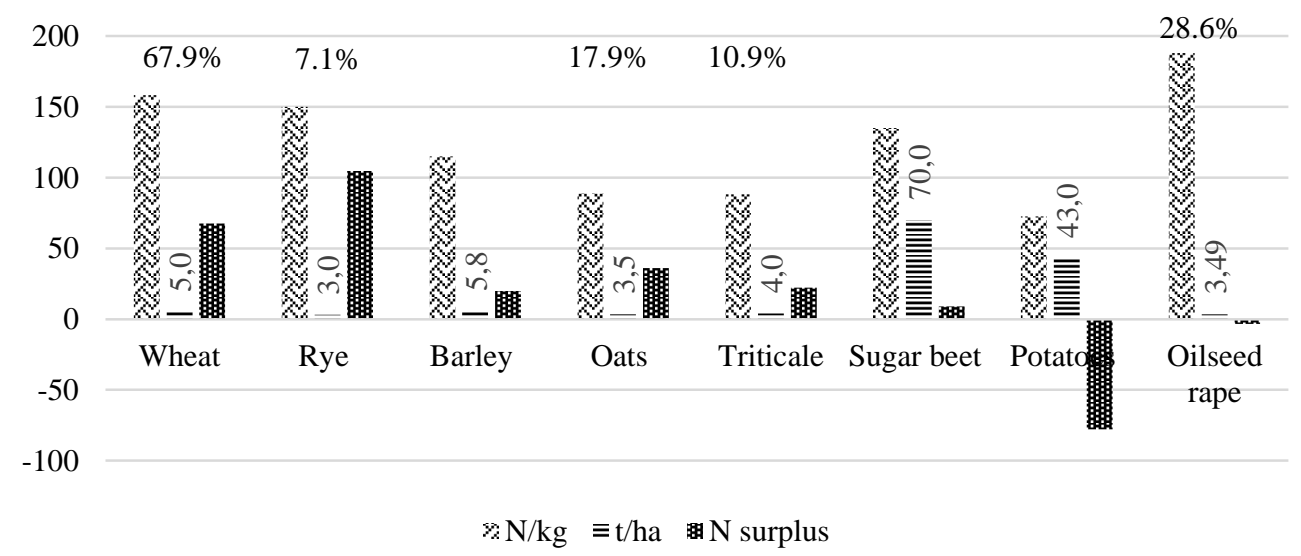

Figure 2. Used nitrogen, yield and nitrogen surplus of 2019 yield

Farmers mainly used $\mathrm{N}$ fertilizers $(\mathrm{N} / \mathrm{kg})$ for oilseed rape, wheat, rye, sugar beet. Oilseed rape (28.6\%) and wheat $(67.9 \%)$ were grown the mostly. The yield ( $\mathrm{t} / \mathrm{ha}$ ) indicated 2019 had comparably low yields (Fig. 2). Nitrogen surplus (nitrogen supply minus nitrogen withdrawal with the product) for the most planted crops range from -78 to $104 \mathrm{~kg} \mathrm{~N} / \mathrm{ha}$. Calculated nitrogen surplus shows not only the environmental effects on yield but also nitrogen overuse.

In order to calculate the elasticity, it is needed to know farmers' change in purchase of nitrogen fertilizers if prices were increased by 25,50 or $100 \%$, according to a specific tax. The results showed that with increasing prices, farmers would reduce nitrogen purchases (Fig. 3).

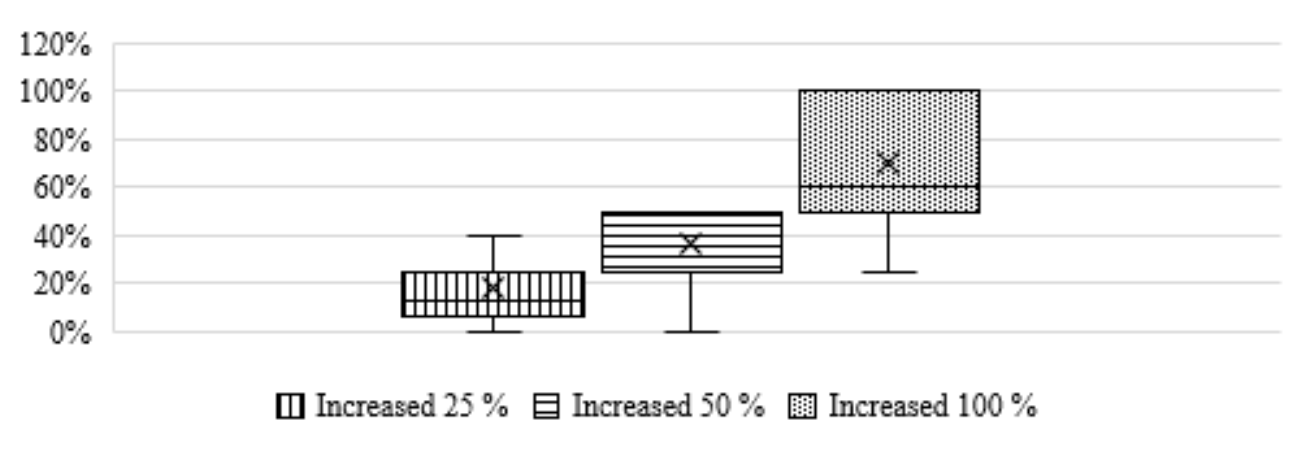

Figure 3. Box plot of decreased purchase of the $\mathrm{N}$ increased price scenarios 
The range of responses increased with the tax. A tax of $25 \%$ would result in a reduced purchase of fertilizer from 0 to $40 \%$ less. If price increased by $50 \%$, farmers would buy from 20 to $50 \%$ less. Accordingly, the last scenarios encourage to buy less fertilizer. With the last one could be reached an area where refusing to buy any fertilizers or drastically reducing their purchase.

On average, a price elasticity coefficient of demand was found approximately at 0.7 (Tab.1). The relationship between price movement and purchase is inverse. Farmers would use less $\mathrm{N}$ fertilizers but even if the price is increased by $100 \%$, it would not encourage them to refuse mineral fertilizer using, confirming the inelasticity of the demand, which has been stated in earlier studies. The main difference between this study results and previous research is that the price elasticity coefficient of demand is based on farmers' opinions and reactions. Results show a bit lower inelasticity coefficient than in studies where were applied calculations from statistical price changes and purchase statistics.

Table 1. Price elasticity coefficient of demand

\begin{tabular}{cc}
\hline Price change (\%) & Price elasticity coefficient of demand (on average) \\
\hline 25 & 0,69 \\
\hline 50 & 0,66 \\
\hline 100 & 0,7 \\
\hline
\end{tabular}

Farmers expressed the opinion in the last open question for the comments. They claim that fertilizer prices are already high. Some of them argue they would refuse agricultural activities if the nitrogen price increases very high. One important aspect related to fertilizer price is farmers' income which is related with such an input as fertilizers ("nitrogen fertilizers increased yield by $70 \%$ ). Is confronted with the opinion that farmers would change growing crops, e. g. would grow buckwheat which according to them do not need mineral nitrogen fertilizer or refuse farming ("With the sharp rise in fertilizer prices, I would not continue farming"). Farmers would refuse mineral nitrogen fertilizer and start using organic fertilizer and it might have influence organic fertilizer demand. That would reach one of the main mineral nitrogen tax purpose. Some of respondents have started decreasing mineral nitrogen using ("We have already reduced the use of nitrogen. In autumn we sow winter rape, when it sprouts, we plow it"). There were farmers who ask tax exemption for mineral fertilizer.

\section{CONCLUSIONS}

This study has shown that an nitrogen tax in Lithuania might result in reduced fertilizer use among Lithuanian farmers. The response to a tax would be limited to an elasticity of on average 0.7 , confirming the inelasticity of demand, found in other studies. The range of responses indicate that individual farmers probably would react differently, which should be taken into account in further considerations. Nitrogen tax affects the economics of farming, even though the main purpose of an nitrogen tax is not to collect money to the state budget but to reduce negative externalities associated with nitrogen use. Nitrogen tax is a fiscal instrument for reducing environmental pollution and collected money should be brought back to the agriculture sector as returns for farmers or mitigate the effects of environmental pollution. Farmers reaction to an nitrogen tax is negative, it shows negative reaction to the increased fertilizers price. Nitrogen tax can reduce nitrogen use though economic, social and environmental issues which should be taken into consideration.

\section{REFERENCES}

1. Andersen, S. M. 2009. Fertilizer tax in Sweden. 9 p. Available at https://ieep.eu/uploads/articles/attachments/cd57d2c2-6c74-42448201-10c8fff4b7f6/SE\%20Fertilizer\%20Tax\%20final.pdf?v=63680923242 (accessed on 15/08/2021)

2. Brunelle, T., Dumas, P., Souty, F., Dorin, B., Nadaud, F. 2015. Evaluating the impact of rising fertilizer prices on crop yields. Agricultural Economics, Vol. 46(5), pp. 653-666. https://doi.org/10.1111/agec.12161

3. Choi, E. K., Feinerman, E. 1995. Regulation of Nitrogen Pollution: Taxes versus Quotas. Journal of Agricultural and Resource Economics, Vol. 20(1), pp. 122-134.

4. De Schutter, O. 2017. The political economy of food systems reform. European Review of Agricultural Economics, Vol. 44(4), pp. 705-731. https://doi.org/10.1093/erae/jbx009

5. Drake, L. 1998. The Economics of the Swedish Policy to Reduce Cadmium in Fertilisers, Keml PM 2/98

6. European Commission. 2018. Report on the implementation of Council Directive 91/676/EEC concerning the protection of waters against pollution caused by nitrates from agricultural sources based on Member State reports for the period 2012-2015. Available at https://eur-lex.europa.eu/legal-content/en/TXT/?uri=CELEX\%3A52018DC0257 (accessed on 15/08/2021)

7. Finger, R. 2012. Nitrogen use and the effects of nitrogen taxation under consideration of production and price risks. Agricultural Systems, Vol. 107, pp. 13-20. https://doi.org/10.1016/j.agsy.2011.12.001

8. Folkens, L., Wiedemer, V., Schneider, P. 2020. Monetary valuation and internalization of externalities in German agriculture using the example of nitrate pollution: A case-study. Sustainability, Vol. 12(16), 6681. https://doi.org/10.3390/su12166681

9. Freebairn, J. 2020. A Portfolio Policy Package to Reduce Greenhouse Gas Emissions. Atmosphere, Vol. $11(4)$, 337. https://doi.org/10.3390/atmos11040337 
10. Guyomard, H., Bureau J. C. et al. 2020. Research for AGRI Committee - The Green Deal and the CAP: policy implications to adapt farming practices and to preserve the EU's natural resources. European Parliament, Policy Department for Structural and Cohesion Policies, Brussels.

11. Hellsten, S., Dalgaard, T., Rankinen, K., Tørseth, K., Bakken, L., Bechmann, M., Kulmala, A., Moldan, F., Olofsson, S., Piil, K., Pira, K., Turtola, E. 2019. Abating $\mathrm{N}$ in Nordic agriculture - Policy, measures and way forward. Journal of Environmental Management, Vol. 236, pp. 674-686. https://doi.org/10.1016/j.jenvman.2018.11.143

12. Keeler, B. L., Gourevitch, J. D., Polasky, S., Isbell, F., Tessum, C. W., Hill, J. D., Marshall, J. D. 2016. The social costs of nitrogen. Science Advances, Vol. 2(10). https://doi.org/10.1126/sciadv.1600219

13. Meyer-Aurich, A., Weersink, A., Gandorfer, M., Wagner, P. 2010. Optimal site-specific fertilization and harvesting strategies with respect to crop yield and quality response to nitrogen. Agricultural Systems, Vol. 103(7), pp. 478-485. https://doi.org/10.1016/j.agsy.2010.05.001

14. Meyer-Aurich, A., Karatay, Y. N. 2019 Effects of uncertainty and farmers' risk aversion on optimal N fertilizer supply in wheat production in Germany. Agricultural Systems, Vol. 173, pp. 130-139. https://doi.org/10.1016/j.agsy.2019.02.010

15. OECD. 2000. Environmentally Related Taxes in OECD Countries. Issues and Strategies 142.

16. OECD. 2001. Environmentally Related Taxes in OECD Countries. Issues and Strategies. In Oecd. https://doi.org/10.1787/9789264193659-en

17. OECD. 2020. Taxation in Agriculture: Main report. In Taxation in Agriculture. https://doi.org/10.1787/2353a523-en

18. Ottaviani, D., Scialabba, N. E. H. 2001. Payments for Ecosystem Services and Food Security. Food and Agriculture Organization of the United Nations: Rome, Italy.

19. Quddus, M., Siddiqi, M., Riaz, M. 2008. The Demand for Nitrogen, Phosphorus and Potash Fertilizer Nutrients in Pakistan. Pakistan Economic and Social Review, Vol. 46(2), pp. 101-116.

20. Rajsic, P., Weersink, A. 2008. Do farmers waste fertilizer? A comparison of ex post optimal nitrogen rates and ex ante recommendations by model, site and year. Agricultural Systems, Vol. 97(1-2), pp. 56-67. https://doi.org/10.1016/j.agsy.2007.12.001

21. Rougoor, C. W., Van Zeijts, H., Hofreither, M. F., Bäckman, S. 200. Experiences with fertilizer taxes in Europe. Journal of Environmental Planning and Management, Vol. 44(6), pp. 877-887. https://doi.org/10.1080/09640560120087615

22. Schmidt, A., Necpalova, M., Zimmermann, A., Mann, S., Six, J., Mack, G. 2017. Direct and indirect economic incentives to mitigate nitrogen surpluses: A sensitivity analysis. Journal of Artificial Societies and Social Simulation, Vol. 20(4). https://doi.org/10.18564/jasss.3477

23. Staugaitis, G., Vaisvila, Z., Mazvila, J., Arbaciauskas, J., Adomaitis, T., Fullen, M. A. A. 2007. Role of soil mineral nitrogen for agricultural crops: Nitrogen nutrition diagnostics in Lithuania. Archives of Agronomy and Soil Science, Vol. 53(3), pp. 263-271. https://doi.org/10.1080/03650340701223338

24. Štreimikienė, D., Ališauskienė-Šeškienè, I. 2013. Elektros energijos gamybos šaltinių išorinių kaštų Lietuvoje vertinimas. Energetika, Vol. 59(1), pp. 11-19. https://doi.org/10.6001/energetika.v59i1.2615 (In Lithuanian)

25. Sutton, M. A., Oenema, O., Erisman, J. W., Leip, A., van Grinsven, H., Winiwarter, W. 2011. Too much of a good thing? The Role of Choice in Negotiation. Nature, Vol. 472, pp. 159-161. https://doi.org/10.1038/472159a

26. Verma, R., Gayithri, K. 2018. Environmental Fiscal Instruments: A Few International Experiences. Margin: The Journal of Applied Economic Research, Vol. 12(3), pp. 333-368. https://doi.org/10.1177/0973801018768974

27. Von Blottnitz, H., Rabl, A., Boiadjiev, D., Taylor, T., Arnold, S. 2006. Damage costs of nitrogen fertilizer in Europe and their internalization. Journal of Environmental Planning and Management, Vol. 49(3), pp. $413-433$. https://doi.org/10.1080/09640560600601587 